УДК 347.96-055:342

DOI https://doi.org/10.15421/392046

Бухтіярова I. Г.,

кандидат юридичних наук,

старший викладач кафедри публічного управління та адміністрування

Національної академії внутрішніх справ

Бухтіяров О. А.,

кандидат юридичних наук,

доиент кафедри спеціальних дисииплін та організаиії професійної підготовки

Університету державної фіскальної служби України

\title{
ОСОБЛИВОСТІ ГЕНЕЗИСУ ГЕНДЕРНОГО НАСИЛЬСТВА
}

\section{FEATURES OF GENESIS OF GENDER VIOLENCE}

\begin{abstract}
Стаття присвячена висвітленню однієї з актуальних тем сьогодення. Зроблене дослідження генезису розвитку гендерного
\end{abstract} насильства в Україні.

Ми живемо у світі, однією з характерних ознак якого є насильство. Найчастіше воно зустрічається у вигляді фізичного чи психологічного насильства. А останні десятиріччя з'явився новий вид насильства - гендерне. Найпоширенішими видами гендерного насильства у світі вважаються згвалтування, домашнє насильство (або насильство в сім’і), проституція, секс-торгівля, сексуальні домагання.

Гендерне насильство - це насильство, яке чиниться над особою тому, що вона належить до тієї чи іншої статі. Переважна частина гендерного насильства чиниться чоловіками над жінками. Метою гендерного насильства, як і будь-якого іншого насильства, $є$ прагнення до домінування та контролю поведінки. Гендерне насильство має форми фізичного, сексуального, економічного, а також психологічного приниження, яке здійснюється шляхом експлуатації, дискримінації, погроз і репресій. Сім'я є головним місцем гендерного насильства, яке найчастіше відбувається відносно жінки. Насильство відносно жінки спричиняє страждання не лише їй, а й всій сім’ї, і стає каталізатором для зародження гендерного насильства. Згідно зі статистичними даними, кожен сьомий чоловік був свідком фізичного насильства стосовно матері з боку батька. Такий досвід має негативний вплив на дитячу психіку й може призводити до сприйняття домашнього насильства як норми в стосунках. Гендерна нерівність, гендерні стереотипи, а також такі особисті психологічні особливості, як агресивність, прагнення домінування лежать в основі гендерного насильства. Там, де $\epsilon$ насильство й агресія, не може бути й думки про розвиток цивілізованого суспільства. Вважаємо, потрібно виховувати в суспільстві взаємну повагу й доброзичливість від одного до іншого для того, щоб знизити «градус» агресії та жорстокості спочатку в сім’ї, а потім в суспільстві, що своєю чергою посприяє зниженню насильства за ознакою статі.

Лише за умови викорінення гендерного насильства ми зможемо жити в правовій, демократичній та квітучій країні.

Ключові слова: жінка, фізичне насильство, психічне насильство, статеве насильство, гендерна нерівність.

The article is dedicated to highlighting one of the topical topics of today. The study of the genesis of the development of genderbased violence in Ukraine has been done.

We live in a world that is one of the hallmarks of violence. Most often it occurs in the form of physical or psychological abuse. And in recent decades, a new kind of violence has emerged - gender. The most common types of gender-based violence in the world are rape, domestic violence (or domestic violence), prostitution, sex trafficking, and sexual harassment.

Gender-based violence is violence that is perpetrated against a person because they are of a particular gender. The vast majority of gender-based violence is committed by men against women. The goal of gender-based violence, like any other violence, is the desire to dominate and control behavior. Gender-based violence takes the form of physical, sexual, economic and psychological humiliation through exploitation, discrimination, threats and repression. The family is the mainstay of gender-based violence, most often against women. Violence against a woman causes suffering not only for her, but for the whole family, and becomes a catalyst for the emergence of gender-based violence. Given that, according to statistics, one in seven people has witnessed physical violence against their mother by their father. Such experiences have a negative impact on the child's psyche and can lead to the perception of domestic violence as the norm in relationships. Gender inequality, gender stereotypes, as well as personal psychological traits such as aggression and the desire to dominate are at the heart of gender violence. Where there is violence and aggression there can be no thought about the development of a civilized society. We believe we need to foster mutual respect and goodwill from one society to another in order to reduce the "degree" of aggression and cruelty first in the family and then in society, which in turn contributes to reducing gender-based violence.

Only if gender violence is eradicated will we be able to live in a legal, democratic and prosperous country.

Key words: woman, physical abuse, mental violence, sexual violence, gender inequality.

Ми живемо у світі, однією з характерних ознак якого є насильство. Найчастіше воно зустрічається у вигляді фізичного чи психологічного насильства. 3'ясувалося, що $є$ певні форми насильства, про які ще років п'ятдесят тому не прийнято було говорити або визначати таку поведінку як насильство. Питання щодо гендерного насильства були і є предметом дослідження науковців. В Україні це питання вивчали такі науковців як В. Смолій, Т. Марценюк, І. Воло- севич, Т. Коноплицька, Т. Костюченко, В. Галунько, Т. Коломоєць, О. Стрельченко та інші.

Мета цієї статті зумовлена актуальністю проблеми й становить дослідження генезису й розвитку гендерного насильства в Україні.

Жінки, які боролися за свої права, виходили на вулиці зі слоганами «Особисте - це політичне». Вони мали на увазі також і насильство в сім'ї, в приватній сфері, яка мало регулювалася державою. 
Інші групи жінок виступали проти примусових шлюбів або так званого «жіночого обрізання» (практики, які досі трапляються в країнах Африки чи Азії). Виявилося, що такі форми насильства, які стосуються радше приватного життя, - велика проблема, яка потребує вирішення.

Тому Організація Об'єднаних Націй (далі - ООН) вирішила виділити окремий тип насильства - гендерне насильство або насильство проти жінок (поширена міжнародна абревіатура VAW - violence against women), в основі якого лежать владні стосунки між чоловіками й жінками [1].

Гендерне (гендероване) насильство - це форми насильницьких дій, що мають чітко виражену гендерну групу, на яку спрямоване насильство або яка чинить насильство. Гендерне насильство в основному сприймається як насильство проти жінок, яке чинять переважно чоловіки. Водночас чоловіки, від яких очікується агресивна поведінка, не лише чинять насильство, а й самі страждають від нього (у війнах, розбоях, вуличному насильстві). Тому вони є як агресорами, так і жертвами насильницької поведінки [2].

Особливостями зазначеного виду насильства $€$ те, що найчастіше це насильство здійснюється в приватному просторі (домашнє насильство), тому його погано розпізнають і карають органи правосуддя. Це проблема XXI століття, актуальна для всіх країн світу, немає жодної країни, де цю проблему було б розв'язано. Найстрашнішою ознакою $є$ те, що дуже часто це насильство пояснюють «культурою», традиціями й звичками. Важливою ознакою треба зазначити, що проблема перейшла 3 «приватної» сфери в публічну (тобто особисте стало політичним), тому наразі потребує вирішення на державному рівні. Для подолання цієї проблеми потрібні спільні зусилля дослідників, політиків, громадських активістів, засобів масової інформації та кожного громадянина суспільства [3].

Ще одна важлива ознака гендерного насильства - це радше так зване не вуличне насильство, тобто жертва може знати насильника. I дійсно, у випадку згвалтувань доволі часто насильниками $\epsilon$ не невідомі чоловіки, а знайомі жінці люди. Тобто проблема в тому, що це той тип насильства, яке не завжди очікується, адже ми звикли вважати, що «наш дім - це наша фортеця», що в приватній сфері, в сім’ї ми можемо почуватися захищено.

Найпоширенішими видами гендерного насильства у світі вважаються згвалтування, домашне насильство (або насильство в сім'ї), проституція, секс-торгівля, сексуальні домагання.

Гендерне насильство - це насильство, яке чиниться над особою тому, що вона належить до тієї чи іншої статі. Переважна частина гендерного насильства чиниться чоловіками над жінками. Метою гендерного насильства, як і будь-якого іншого насильства, є прагнення до домінування та контролю поведінки. Гендерне насильство має форми фізичного, сексуального, економічного, а також психологічного приниження, яке здійснюється шляхом експлуатації, дискримінації, погроз і репресій.
Сім'я є головним місцем гендерного насильства. У родині відбувається насильство фізичне, психологічне, сексуальне. Ще однією формою гендерного насильства в сім'ї є прямий контроль жіночої сексуальності: примусові аборти й примусові вагітності. Іншим осередком насильства над жінками є робоче місце - як на державній, так і на приватній службі. Місце роботи може містити як сексуальну агресію (переслідування, залякування), так і торгівлю жінками й примусову проституцію. Гендерне насильство $\epsilon$ грубим порушенням прав людини. На протидію йому спрямовано багато міжнародних документів, зокрема Конвенція ООН про ліквідацію всіх форм дискримінації щодо жінок, Декларація ООН про викорінення насильства проти жінок. У багатьох випадках гендерне насильство є порушенням українського законодавства, може кваліфікуватись як адміністративне правопорушення або кримінальний злочин. Гендерна нерівність, гендерні стереотипи, а також такі особисті психологічні особливості, як агресивність, прагнення домінування лежать в основі гендерного насильства.

Вивчаючи причини, які призводять до появи гендерного насильства, можна зрозуміти, що однією 3 причин, з одного боку, є навколишній світ як приклад того, як треба поводитися та яким ідеалам відповідати, а $з$ іншого - традиції народу. Так, найчастіше, описуючи ідеал чоловічості, зазначають, що це сильний воїн, в якого перевага завжди на боці сили. Але молоді чоловіки дуже часто стають свідками фізичного насильства відносно матері з боку батька. Такий досвід має негативний вплив на дитячу психіку й може призводити до сприйняття домашнього насильства як норми в стосунках. Спільнота нав'язує громадське лідерство, пов'язуючи його з домінуванням над іншими.

В українському суспільстві зберігаються стійкі очікування щодо моделей подружніх стосунків, відповідно до яких за чоловіками закріплюється роль годувальника родини, а на жінок покладаються зобов'язання щодо ведення господарства, піклування про родину й догляду за дітьми. На жаль, в питаннях планування сім’ї значна частина чоловіків зберігають досить патріархальні погляди.

Патріархальні очікування щодо «належної» поведінки жінки призводить до поширення настанов віктимізації потерпілих від сексуального насильства, звинувачення їх у провокуванні насильницьких дій власними вчинками або способом життя, нерозбірливістю в спілкуванні з представниками протилежної статі.

Досить поширеними серед чоловіків залишаються i настанови на толерування домашнього насильства. Значною мірою причини такого ставлення пов'язані з глибоко вкоріненим сприйняттям нерівного значення жінок і чоловіків в суспільстві, зокрема підлеглого становища жінок в ієрархії сімейних стосунків.

Відповідно, атрибути «гарної» дружини часто пов'язуються 3 поступливістю, прагненням дослухатися до чоловіка й уникати конфліктних ситуацій у родині. Зокрема, проведені опитування дають 
можливість стверджувати наступне: чоловіки у своїй більшості вважають, що «гарна» жінка не повинна ставити під сумнів думку й рішення чоловіка, навіть якщо вона $з$ ними не погоджується [6].

Невідповідність реального сімейного життя цим очікуванням закономірно призводить до конфліктів, розгортання яких може супроводжуватися виявами агресії та насильства. Як результат, досить поширеними в громадській свідомості залишаються культурні практики, які визнають право чоловіків застосовувати фізичні покарання до власних дружин у певних випадках.

Зокрема, 13\% чоловіків, які були опитані в рамках дослідження, вважали, що побиття дружини власним чоловіком може бути виправданим у деяких ситуаціях, 18\% чоловіків погодилися, що чоловік має право вдарити або побити власну дружину, якщо він дізнався про іï зраду, 5\% чоловіків - якщо дружина відмовляє чоловікові в інтимних стосунках. Водночас кожен десятий респондент дослідження підтримав думку, що жінка повинна терпіти прояви насильства з боку чоловіка, щоб зберегти власну сім'ю [6].

Підставою, яка пояснює так звану культуру, традиції та звички, є наявність великої кількості різних культурних форм, якими можна проілюструвати гендерне насилля. Наприклад, нині в деяких країнах світу легально застосовують лапідацію - публічну смертну кару, коли чоловіки закидають камінням жінку, звинувачену в подружній зраді. Агресори й жертва в цьому випадку визначені статтю та не можуть помінятись місцями. Іншим прикладом гендерного насилля може бути звичай «викрадення наречених», що практикують у деяких країнах. Нерідко таке викрадення є зовсім не домовленою, взаємоузгодженою грою, а реальним насиллям, злочином. Дівчину викрадають просто на вулиці, наприклад, коли вона йде на заняття в університет, а щоб вона не втекла, іiі гвалтують. Повернутися додому «збезчещена» дівчина не може, бо завдасть сорому своїй сім’ї, рідні ії цуратимуться. Єдиний спосіб «виправити» ситуацію для неї - це вийти заміж за крадія та гвалтівника [4].

Всесвітня організація охорони здоров'я (далі BOO3) окрему увагу звертає на сексуальне насильство щодо жінок з боку інтимного партнера (intimate partner and sexual violence against women) [5]. BOO3 наводить таку класифікацію видів насильства відповідно до життєвого циклу жінки:

- до народження - селективні за статтю аборти;

- дитинство - жіноче дітовбивство, фізичне, сексуальне й психологічне насильство;

- дівоцтво - дитячий шлюб; обрізання жіночих статевих органів, фізичне, сексуальне й психологічне насильство, інцест; дитяча проституція та порнографія;

- підлітковий вік $i$ повноліття - насильство в процесі залицяння та зустрічей (наприклад, згвалтування від інтимного партнера, обливання кислотою), сексуальні стосунки через економічну необхідність; інцест, згвалтування, сексуальні домагання, примус до проституції та порнографії, торгівля жінками, примусовий секс у шлюбі, насильство з боку партнера, вбивство з боку партнера, психологічне насильство, зловживання жінками 3 інвалідністю, примусова вагітність;

- літній вік - примусове «самогубство», сексуальне, фізичне і психологічне насильство [5].

Викладений матеріал дає підстави вважати, що проблема гендерного насильства потребує комплексного вирішення на всіх рівнях, а особливо на державному. Зародження проблеми найчастіше постає саме в ранньому віці, в період зростання насамперед у сімейному середовищі, тому стратегічним завданням сьогодення $є$ втілення заходів у напрямку формування самодостатньої сім’ї, запобігання насильства в сім’і, протидії торгівлі людьми й гендерної рівності. Не зайвим буде залучення не лише держави, а й громадських організацій та суспільства щодо впровадження в життя масштабних проєктів і заходів, які будуть сприяти набуттю молодими людьми умінь i навичок сімейного життя, гармонійному розвитку кожного члена сім'ї, підтримці позитивного психологічного клімату, зміцненню подружніх стосунків, а також налагодженню взаєморозуміння між батьками й дітьми. Повага, насамперед до людини, до ііі поглядів, інтересів, вподобань повинна стати першочерговою ознакою людських відносин не залежно від статі. Лише взаємна повага й доброзичливість від одного до іншого може знизити «градус» агресії та жорстокості спочатку в сім’ї, а згодом у суспільстві, що своєю чергою посприяє зниженню насильства за ознакою статі.

\section{ЛІТЕРАТУРА}

1. Гендерне насильство: що? де? коли? Ресурсний центр ГУРТ : вебсайт. URL: https://gurt.org.ua/.

2. Гендерне насильство. Вікіпедія: вільна енциклопедія. URL: https://uk.wikipedia.org/wiki/\%D0\%93\%D0\%B5\%D0\%BD\% D0\%B4\%D0\%B5\%D1\%80\%D0\%BD\%D0\%B5_\%D0\%BD\%D0\%B0\%D1\%81\%D0\%B8\%D0\%BB\%D1\%8C $\%$ D $1 \% 81 \% \mathrm{D} 1 \% 82 \%$ $\mathrm{D} 0 \% \mathrm{~B} 2 \% \mathrm{D} 0 \% \mathrm{BE}$.

3. Марценюк Т. Годі терпіти: усе про гендерне насильство проти жінок. Гендер в деталях : вебсайт. URL: https://genderindetail.org.ua/season-topic/genderne-nasilstvo/godi-terpiti-use-pro-genderne-nasilstvo-proti-zhinok-134410.html.

4. Маєрчик М., Плахотнік О. Гендероване насильство: між злочином і звичаєм [Електронний pecypc]. URL: http://ekmair.ukma.edu.ua/bitstream/handle/123456789/15670/Maierchyk_\%20Henderovane_nasylstvo_mizh_zvychaiem_i_ zlochynom.pdf? sequence $=1 \&$ is Allowed $=y$.

5. Definition and scope of the problem. Violence against women. Всесвітня організація охорони здоров'я : вебсайт. URL: https://www.who.int/.

6. Як українські чоловіки ставляться до гендерних стереотипів і насильства щодо жінок. Thedevochki : вебсайт. URL: $\quad$ http://thedevochki.com/?s=\%D0\%AF\%D0\%BA+\%D1\%83\%D0\%BA\%D1\%80\%D0\%B0\%D1\%97\%D0\%BD $\%$ D $\%$ D $\% 81 \%$ D1\%8C \%D0\%BA\%D1\%96+\%D1\%87\%D0\%BE\%D0\%BB\%D0\%BE\%D0\%B2\%D1\%96\%D0\%BA\%D0\%B8+\%D1\%81\%D1\% $82 \% \mathrm{D} 0 \% \mathrm{~B} 0 \% \mathrm{D} 0 \% \mathrm{~B} 2 \% \mathrm{D} 0 \% \mathrm{BB} \% \mathrm{D} 1 \% 8 \mathrm{~F} \% \mathrm{D} 1 \% 82 \% \mathrm{D} 1 \% 8 \mathrm{C} \% \mathrm{D} 1 \% 81 \% \mathrm{D} 1 \% 8 \mathrm{~F}+\% \mathrm{D} 0 \% \mathrm{~B} 4 \% \mathrm{D} 0 \% \mathrm{BE}+\% \mathrm{D} 0 \% \mathrm{~B} 3 \% \mathrm{D} 0 \% \mathrm{~B} 5 \%$ D0\%BD $\%$ D0 $\%$ B4\%D0\%B5\%D1\%80\%D0\%BD\%D0\%B8\%D1\%85+\%D1\%81\%D1\%82\%D0\%B5\%D1\%80\%D0\%B5\%D0\%BE\% D1\%82\%D0\%B8\%D0\%BF\%D1\%96\%D0\%B2+\%D1\%96+\%D0\%BD\%D0\%B0\%D1\%81\%D0\%B8\%D0\%BB\%D1\%8C \%D1\% $81 \% \mathrm{D} 1 \% 82 \% \mathrm{D} 0 \% \mathrm{~B} 2 \% \mathrm{D} 0 \% \mathrm{~B} 0+\% \mathrm{D} 1 \% 89 \% \mathrm{D} 0 \% \mathrm{BE} \% \mathrm{D} 0 \% \mathrm{~B} 4 \% \mathrm{D} 0 \% \mathrm{BE}+\% \mathrm{D} 0 \% \mathrm{~B} 6 \% \mathrm{D} 1 \% 96 \% \mathrm{D} 0 \% \mathrm{BD} \% \mathrm{D} 0 \% \mathrm{BE} \% \mathrm{D} 0 \% \mathrm{BA}$. 